\title{
WEST MEXICAN STELAE FROM JALISCO AND NAYARIT
}

\section{Joseph B. Mountjoy}

Department of Anthropology, University of North Carolina, Greensboro, NC 27412-5001, USA

\begin{abstract}
The process of Mesoamerican cultural expansion into western and northwestern Mexico has been a subject of speculation and investigation for over three centuries. Although many cultural traits have been "implicated" in this process, the practice of erecting stelae has not been one of them. Fieldwork by the author in Jalisco and Nayarit over the past

14 years has resulted in the discovery of 48 stone monuments which are proposed to be rustic versions of the us ually more sophisticated stelae associated with cultures of central Mesoamerica. These west Mexican stelae are described and discussed in terms of their context, date, and possible function. Similar stone monuments from other sites in western and
\end{abstract}

northwestern Mexico are also described, and relevant ethnohistoric data are presented. Finally, the diffusion of the practice of erecting stelae is discussed in relation to the process of mesoamerieanization in western and northwestern Mexico.

THE NORTHWESTERN EXPANSION

OF MESOAMERICA

A long-standing problem in Mesoamerican Prehispanic studies has been the extent of mesoamericanization of northwestern Mexico, including both how and when mesoamericanization occurred. As early as 1650, Tello (1968:26-27) described the great fortified center of La Quemada, Zacatecas, and related it to the ethnohistoric accounts of the legendary wanderings of the Mexica. Subsequent investigators also related these ruins to Mexica culture or to the Tarascans (Batres 1903). In 1908, Gamio (1910) excavated at Alta Vista, Zacatecas, and recognized that site as marking the northernmost limit of several architectural traits which linked it to central Mexican cultures. Then, in a pioneering archaeological study of the Nayarit and Sinaloa coastal plain, Sauer and Brand (1932) focused on the problem of a "cultural corridor" which might link central Mexico with the native cultures of the southwestern United States. Their fieldwork revealed the presence of a highly developed Prehispanic culture in Nayarit and Sinaloa that they called Aztatlán. A few years later, Mason (1937) reported on Prehispanic sites of high cultural development, identified as the Chalchihuites culture, which were found to extend into northwestern Durango as far as the site of Zape (see also Brand 1939). Next, studies by Ekholm $(1940,1941,1942)$ and Kelly (1941) made further contributions to the problem of northwest Mexico/central Mexico Prehispanic relations, and ties between central Mexico and the eastern part of West Mexico were studied by Noguera (1942), Lister (1949), and Porter (1956).

Another major contribution to this problem was made by Kirchhoff in his classic study of 1943, in which he delimited the geographic boundaries of Mesoamerican culture based on sixteenth-century ethnographic traits. His demarcation of the northern boundary revealed a salient of Mesoamerican culture protruding far northwest into Durango and Sinaloa (Kirchhoff
1943). In regard to time depth, Kirchhoff (1948:134-135) later suggested that at some time in the past western Mexico did not pertain to Mesoamerica, and that there must have been a gradual mesoamericanization of the area. He noted that the closer one gets to Jalisco, Colima, and Nayarit, the less Mesoamerican and more specifically western Mexican are the culture traits. He went on to propose that west Mexican studies ought to establish the ways in which that area contrasts with the rest of Mesoamerica.

More recently, investigations by Armillas (1964), Kelly and Braniff de Torres (1966), Kelley and Abbott (1966), Sáenz (1966a, 1966b), Matos and Kelly (1974), Oliveros (1974), Pickering (1974, 1985), Schöndube (1974, 1980), Kelley (1974), Weigand (1974, 1978, 1985), Kelley and Kelley (1976), Aveni, Hartung, and Kelley (1982), Kelly (1985), and Trombold (1985) have shown a continued interest in determining the relationships between the northwestern peripheral area of Mesoamerica and the Mesoamerican heartland.

Some of the archaeological traits that have been cited as perhaps indicating a degree of mesoamericanization of the northwestern area at one time or another are rare Olmecoid artifacts, Thin Orange pottery, talud-tablero architecture, astronomical petroglyph markers, cloisonné pottery, human sacrifice, the skull rack, Mazapan pottery figurines, Plumbate pottery, Mixtec codex-like designs on pottery, and representations of various central Mexican deities. There is evidence of contacts between heartland Mesoamerica and northwestern peripheral Mesoamerica from at least Middle Formative times through the Classic and into the Postclassic period.

\section{THE EXTENSION OF STELAE INTO NORTHWESTERN MESOAMERICA}

One archaeological trait that has not been researched in regard to the mesoamericanization of northwestern Mexico is the stela. 


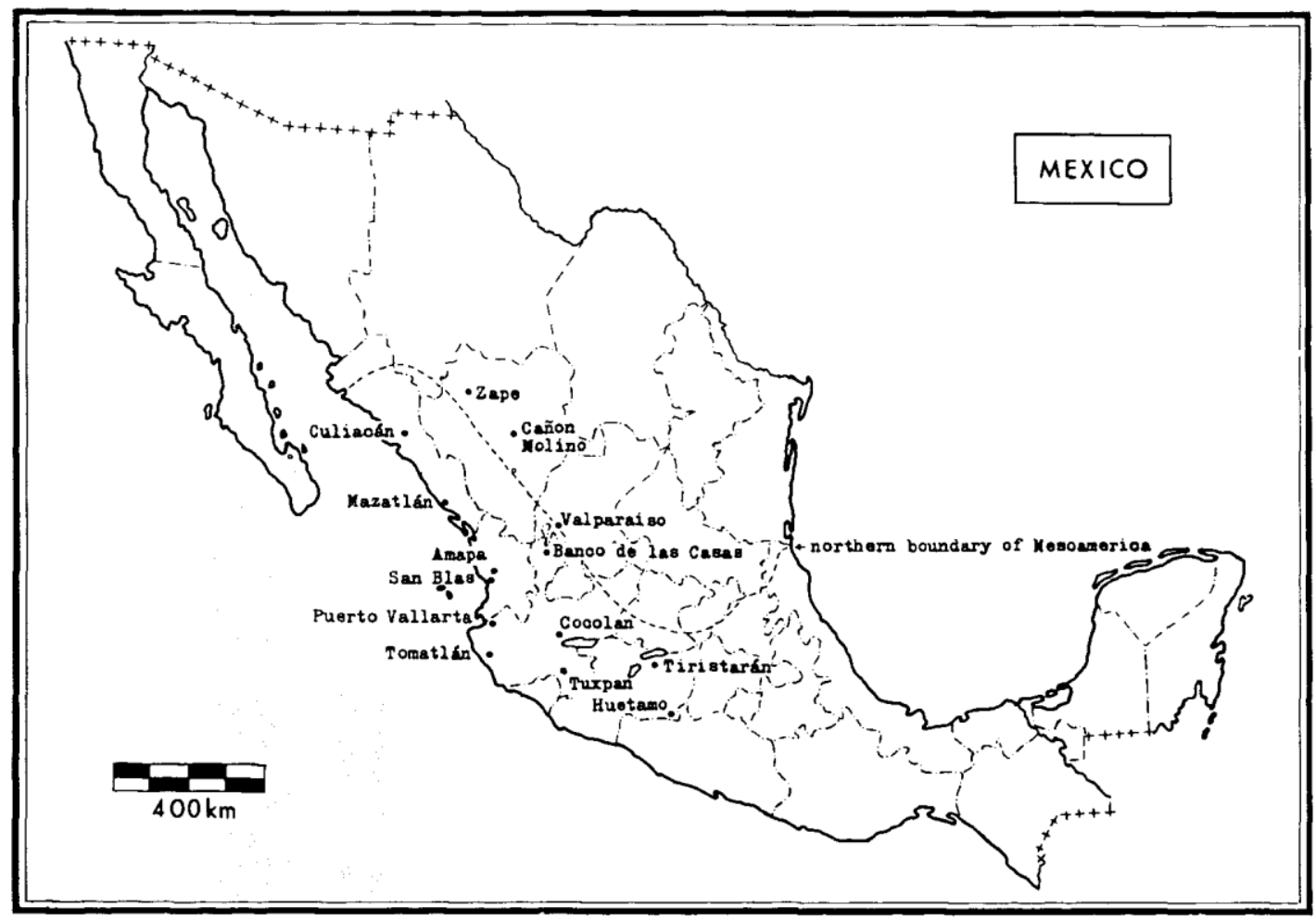

Figure 1. Map of locations in western and northwestern Mexico which have stone monuments mentioned in the text.

Such stone monuments, especially those attributed to the Maya, are one of the more outstanding archaeological remnants of Mesoamerican ceremonialism.

The practice of erecting stelae appears to have originated during the Middle Formative period (Grove 1989; Lowe 1989). Formative period stelae have been reported in some abundance from the Mexican states of Veracruz, Tabasco, Chiapas, Oaxaca, and Morelos, as well as from southern Guatemala and at least one from Belize (Hammond 1982; Marcus 1976). The farthest extension of the stela trait northwestward during the Formative appears to be into Guerrero (Grove and Paradis 1971; Martinez 1986).

Classic period stelae have been found throughout most of Maya territory (Proskouriakoff 1950), as well as in the Mexican states of Oaxaca (Brockington 1957; Jorrin 1974), Morelos (Sáenz 1966c), Puebla (Marquina 1970; von Winning 1979), Queretaro (Carlos Castañeda, personal communication, 1985), Veracruz (Cervantes 1976; Kelly 1982), and they are relatively common in Guerrero (Diaz 1986; Lister 1971; Muller 1966). The farthest northwestern extension of stela erection recorded for the Late Classic or Epiclassic is into the border area of southeastern Michoacan near Huetamo (Figure 1) (Chadwick 1971; Osborne 1943).

Mesoamerican stela production appears to decline rapidly in the Postclassic, but stelae which may date to the Postclassic period have been found in El Salvador (Kelly 1982), the northern Yucatan Peninsula (Proskouriakoff 1950), in the Peten, Guatemala (Bullard 1970), and in the Mexican states of Oaxaca, Puebla, Mexico, and Veracruz (Jorrin 1974; Kelly 1982). The farthest northwestern extension of Postclassic stelae is recorded to be at Huetamo in southeastern Michoacan (Figure 1) (Chadwick 1971).
Certainly, the diffusion of the practice of erecting stelae into northwestern Mexico would be another clear sign of mesoamericanization, but the published literature on the matter indicates that with the exception of a corner of southeastern Michoacan, northwestern Mexico did not participate in this important expression of Mesoamerican ceremonialism at any period. However, this article presents evidence that stelae were erected in many areas of northwestern Mexico in Prehispanic times, although the expression of this Mesoamerican trait was altered in both form and function to suit better the cultural context into which it was introduced, apparently by stimulus diffusion.

\section{DEFINITION OF A STELA}

A stela is "an upright stone slab or pillar bearing an inscription or design and serving as a monument, marker, or the like" (Random House Dictionary of the English Language 1966: 1391) or "a slab or pillar of stone usually carved or inscribed and used for commemorative purposes (as to mark a grave)" (Webster's Third New International Dictionary of the English Language [unabridged] 1966:2235). Although it is common for stelae in the Mesoamerican heartland to be rather tall $(2.44 \mathrm{~m}$ to $3.05 \mathrm{~m}$ ) (Morley 1956:308), generally rectangular, and the surface of the stone pecked or carved in such a way that there are designs which stand out in low relief, none of these characteristics seems essential for defining a stone as a stela. In her extensive study of Classic Maya sculpture, Proskouriakoff (1950:204) defined "stela" simply as:

An upright independent monument. Usually in the form of a thick slab, approximately rectangular or slightly wedgeshaped in form and often rounded on the upper end. 
Even in the Maya area many rock pillars identified as stelae bear no carved or pecked inscriptions, although it is possible they once bore painted designs (Brockington 1957:96-97). Furthermore, stones identified as stelae in some areas of Mesoamerica, Oaxaca, for example, have considerable variation in height, degree of intentional shaping and in their final form (Gamio 1963; Jorrín 1974).

\section{STELAE FOUND RECENTLY IN JALISCO AND NAYARIT}

\section{Description}

During fieldwork in Jalisco and Nayarit from 1975 through 1990, I or my fieldwork associates discovered 48 stones which I believe are local versions of Mesoamerican stelae. Subsequent investigation of the archaeological and ethnohistorical literature of northwestern Mesoamerica has revealed other stones which may be stelae. First, the 48 stones discovered in Jalisco and Nayarit will be described, and their apparent date and possible function will be discussed. Then, possible stelae found in other sites or areas will be discussed, along with their apparent date and possible function. Last, ethnohistorical data on similar stones will be presented, especially those data which relate to the function of such stones.

Eighteen stelae were found at eight different sites in the Tomatlan river valley of central coastal Jalisco (Figure 1) during fieldwork in 1975-1977 and in 1984. Another stela was discovered in the municipality of San Blas, Nayarit, in 1983 (Figure 1), and 29 more were found in the municipality of Puerto Vallarta during 1986-1990. Basic data on all of these stones are presented in the Appendix. Thirty four of the monuments were found essentially whole; the remaining fourteen were missing one or more portions. Measurements of length, width, and thickness have been recorded for most of the stones, whole or broken. When the measurements recorded in the Appendix are for incomplete portions of the stone, they are enclosed in parentheses and have not been included in the summary statistical characterizations of the monuments.

The height of the stones ranges from $0.60 \mathrm{~m}$ to $2.34 \mathrm{~m}$, with a mean of $1.14 \mathrm{~m}$, a median of $1.07 \mathrm{~m}$, and a standard deviation of $0.43 \mathrm{~m}$. The width ranges from $0.16 \mathrm{~m}$ to $0.72 \mathrm{~m}$, with a mean of $0.34 \mathrm{~m}$, a median of $0.30 \mathrm{~m}$, and a standard deviation of $0.15 \mathrm{~m}$. Thickness ranges from $0.09 \mathrm{~m}$ to $0.32 \mathrm{~m}$, with a mean of $0.17 \mathrm{~m}$, a median of $0.14 \mathrm{~m}$, and a standard deviation of $0.06 \mathrm{~m}$.

The stones give the general impression of being roughly rectangular in outline, and rectangular, triangular, or roundish in cross-section. The complete specimens usually have some degree of pointedness at the top. It is sometimes not clear whether the similarities in form and size were produced through careful selection of naturally shaped stones, or if the form or size was intentionally achieved by breaking, pecking, and grinding. Some intentional shaping is possible for all of the stelae found at the Tom-31 site (Figures 2b and 2d; Figure 3), as well as for some of those found at other sites in the Tomatlan basin. On the other hand, Stela 1 from the Tom-57 site does not appear intentionally shaped, and although Stela 1 from the Tom- 8 site (Figure 2a) has some deliberate chipping along one edge, it mostly was formed naturally, perhaps by river action. The angularity

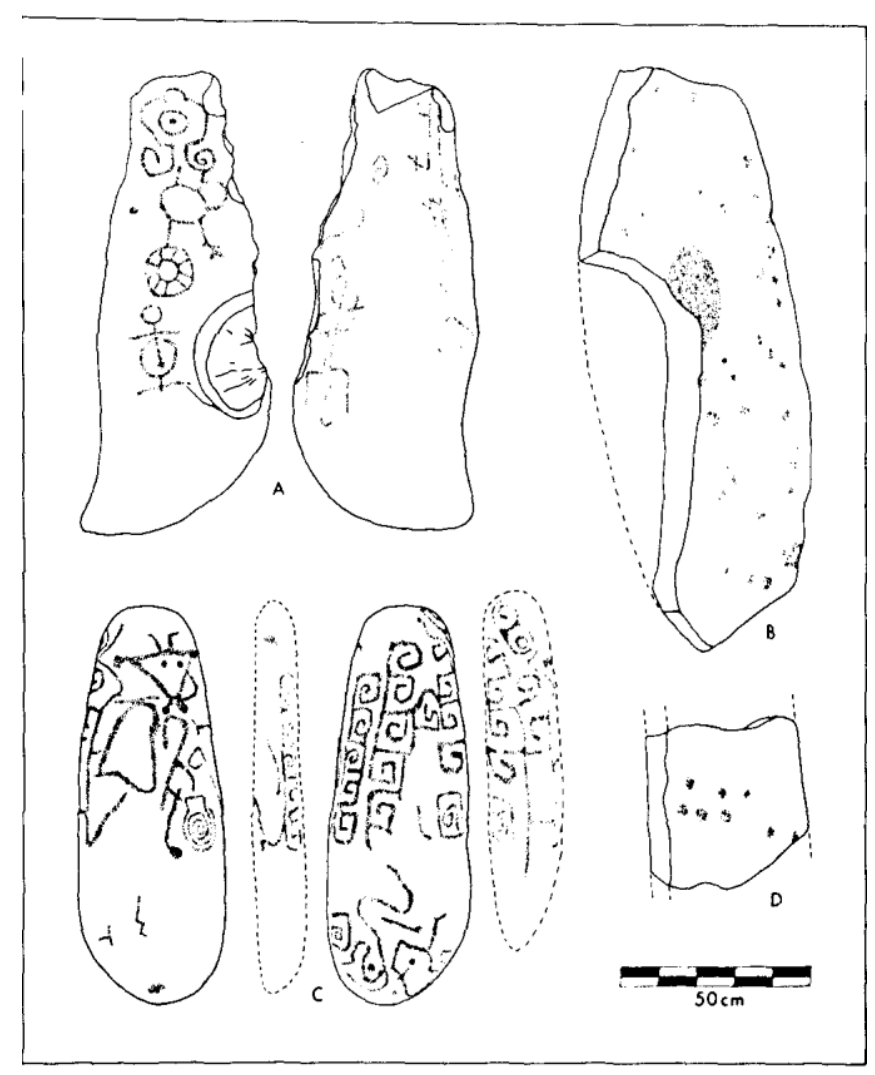

Figure 2. Stelae with petroglyph designs found at sites in the Tomatlar area of Jalisco and the San Blas area of Nayarit: (a) Stela 1 from the Tom. 8 site; (b) Stela 4 from the Tom-31 site; (c) Stela 1 from the SB-1 site; (d) Stela 8 from the Tom-31 site.

of some of the Tomatlan area stelae, for example, Stela 5 at the Tom-31 site and Stela 1 from the Tom-56 site, may indicate selection from rock deposits of the sort commonly exposed by arroyos in the hilly areas close to many of the habitation sites.

Stela 1 from the SB-1 (Aticama) site (Figure 2c) might have been picked up along the cobble-strewn Los Cocos beach nearby, although it certainly would have been a uniquely large cobble. The only possible alteration of this stone is within an area of $0.14 \mathrm{~m}$ by $0.08 \mathrm{~m}$ on the top where the stone may have been intentionally flattened.

One of the stelae (Stela 1) from the PV-1 (Ixtapa) site (Figure 4) was definitely shaped into rectangular form, but the other five stelae at the site appear to have been selected for their natural shape and not further shaped. Such selection of naturally shaped stones seems to be the case for both of the stelae from the PV-12 (Los Cimientos) site. However, the one stela from the PV-15 (La Mesa del Huizcoyul) was definitely shaped into the unusual form of an inverted $\mathrm{T}$ (Figure 5). The expanded base of the stela was apparently designed to better anchor the stone in an upright position. All 20 of the stelae found at the PV-16 (La Soledad) are slivers or slabs of broken rock, but one of them (Stela 5) has large scars where flakes were struck off along the edge of one side, and one other stela (Stela 20) appears extensively pecked into its final form.

The type of rock selected for stelae (Appendix) was often grano-diorite of whitish or cream color, occasionally grading to a bluish diorite which appears slightly harder or denser, or a 


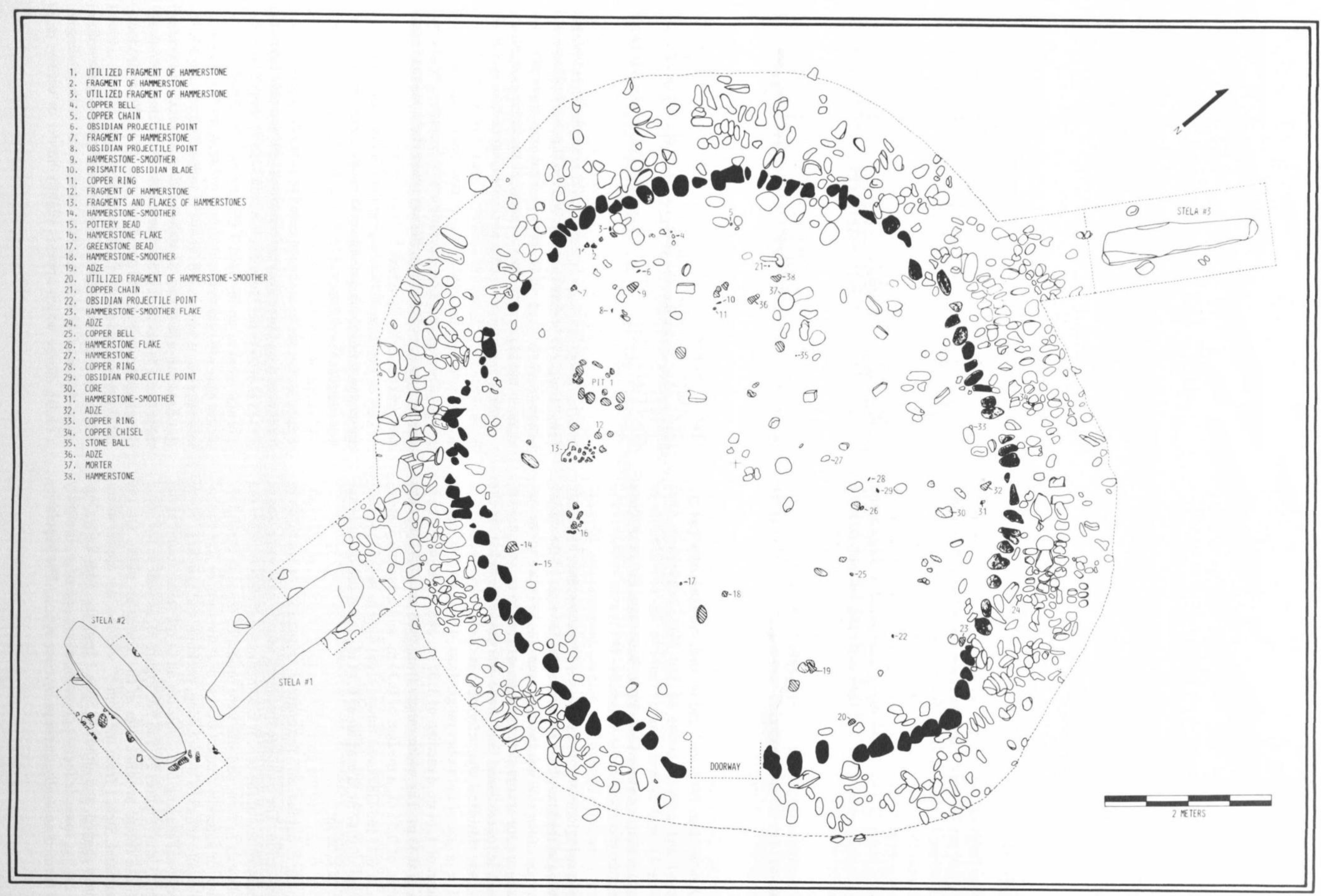

Figure 3. Floor plan of excavated Structure 1 at the Tom-31 site showing the context of Stelae 1, 2, and 3. 


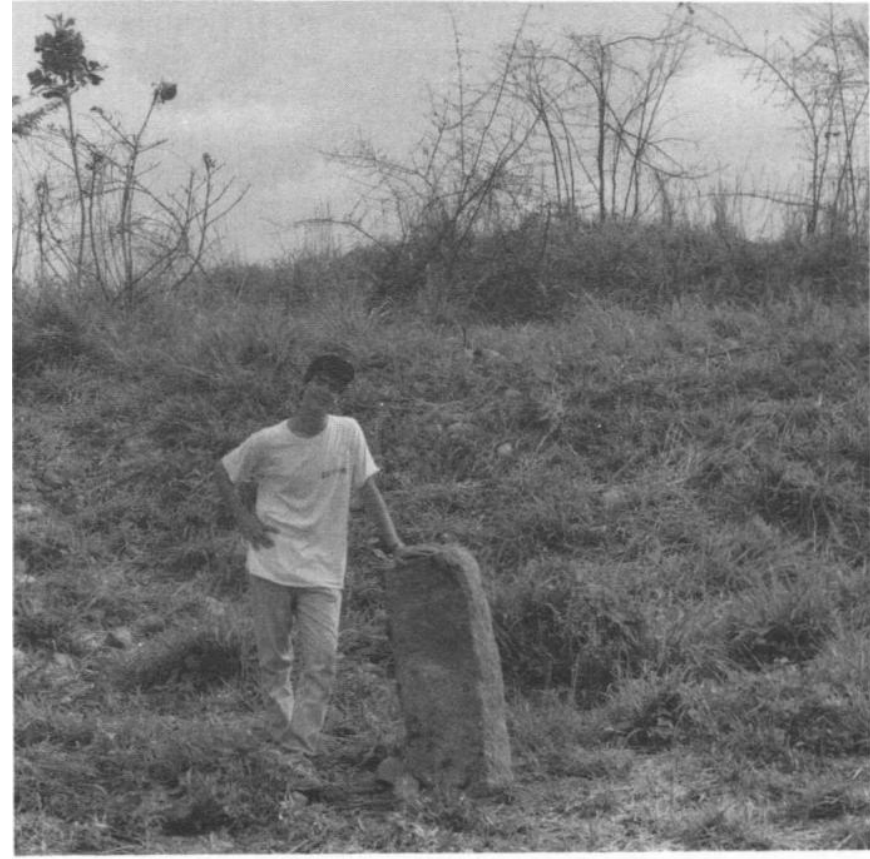

Figure 4. Stela 1 from the PV-1 site, positioned out in front of Mound 2. The lower end of the stone monument, as oriented in the photograph, is missing.

cream, bluish- or reddish-colored rhyolite. Whitish granodiorite is extremely common in the Tomatlan area, but the bluish diorite has been found at only a few places along the Tomatlan river. In the case of Stela 1 at the Tom-57 site, not only was the stela itself of bluish diorite, apparently brought in from a nearby deposit along the river, but also most of the rocks placed around the base of the stela were of the same stone. In several cases, for example at the Tom-31 site, the precise color and grain size of the grano-diorite stelae stones contrasts with the grano-diorite which is native to that particular site locality, indicating a nonlocal source for the stelae stone.

In the San Blas area, fairly soft vesicular basalt is abundant, but grano-diorite of which the stela was made is much less common, although it was frequently utilized for Late Postclassic (Santa Cruz phase) metates and can be found in cobble form along the Los Cocos beach.

In the Puerto Vallarta area rhyolite is the most common type of stela stone, with granite next in frequency, while only one stela of diorite has been recorded. At least the stelae at the PV-I (Ixtapa) site were hauled in from some distant source because such stones are foreign to the flood plain alluvium deposits where the site is located.

Only 4 of the 48 stelae have any designs. In all cases (Figures $2 \mathrm{a}$ to $2 \mathrm{~d}$ ) these designs are petroglyphs, and they appear to have been pecked, as opposed to carved or abraded, into the surface. Two of the stelae were found to have petroglyphs on one side only (Figures $2 \mathrm{~b}$ and $2 \mathrm{~d}$ ); it is therefore possible that these petroglyphs could have been pecked onto the one face after the slabs had fallen over. Thus these petroglyphs might postdate the utilization of the stones as stelae. However, the other two stelae (Figures 2a and 2c) have designs pecked on both the front and back, so these stones must have been standing upright in order for all the petroglyphs to have been visible. In the case of Stela 1 from the Tom- 8 site (Figure 2a), the proper upright

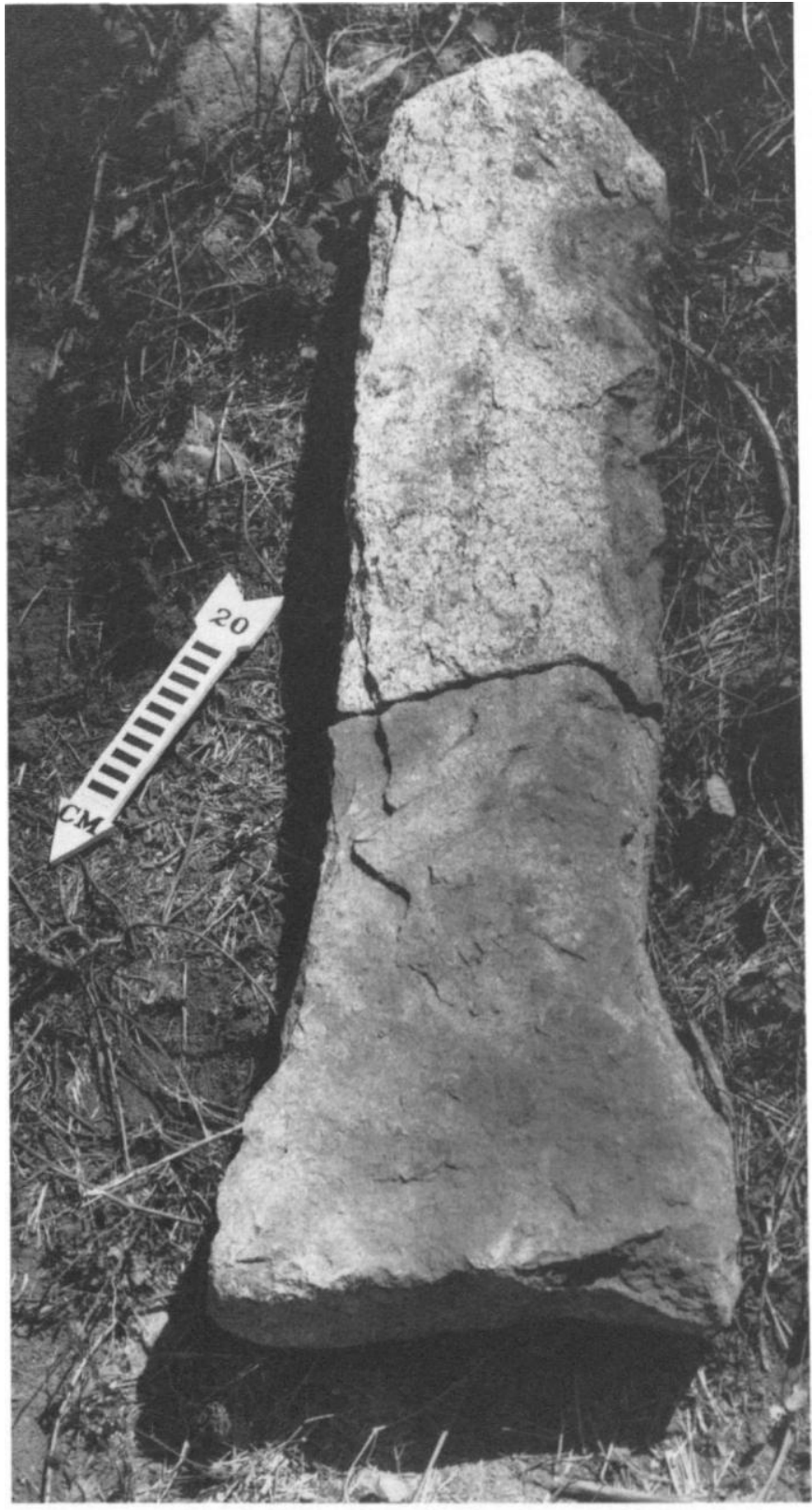

Figure 5. Stela I from the PV-15 site.

orientation of the stela is apparent from the orientation of the anthropomorphic figures pecked into the stone. The base of this stone may lack designs because it was partially sunken into the ground. Stela 1 from the SB- I site (Figure 2c) can likewise be oriented properly upright due to the anthropomorphic head near the top of the stone. There are only three small petroglyphs on one side of the base of the monument, suggesting that the stone may have been positioned at the front of a low platform, of the sort common at the SB-1 site. The stela was found within $5 \mathrm{~m}$ of one such platform; it had apparently been uncovered and pulled out of primary context by agricultural machinery.

\section{Context}

Maps showing the location of stelae in Tomatlan sites 31, 52, 56, 57, and 62 can be consulted in Mountjoy (1982:Figs. 34, 46, 50. and 51. respectivelv). and a map of Tom-8 site can be con- 
suited in Mountjoy (1987b). The two stelae at Tom- 8 were found in the northeastern part of the site. A map of the SB-1 site can be found in Mountjoy (1970:Fig. 9). The SB-1 stela was found along the eastern edge of the cluster of low platforms in the central section in the northeastern part of the site. A map of the PV-1 site can be found in Mountjoy (1989). According to a local informant, all six PV-1 stelae were originally located in front of Mound 2 and were moved to the fence line to facilitate cultivation. The PV-12 stelae were found on the interior side of the rock foundations of a large rectangular structure situated in a plaza some $35 \mathrm{~m}$ from a ceremonial mound. The upper half of the PV-15 stela was found at the foot of the largest ceremonial mound on that site, and the base was found in the adjacent plaza, $14 \mathrm{~m}$ to the northeast. The 20 stelae at the PV-16 site were found in a single plaza adjacent to an area with rock foundations and three ceremonial mounds.

All 19 of the Tomatlan and San Blas stelae were found either within a domestic area, or on the edge of such an area. This is even the case for Stela 1 at the Tom-52 site, where the stela was found on the top of a hill but at the edge of the domestic area. It was found near the earthen foundation of what may have been a sweat bath or menstrual hut. Some terraces, presumably for houses, were located a short distance downslope from the stela.

In the case of Tomatlan sites $31,52,57$, and 62 , the stelae were found within hamlet-sized settlements that contain circular rock foundations of three to eight small houses. These houses open onto one or more plazas on the top or on the side of a hill which has been artificially leveled. Such sites are usually near the Tomatlan river or along a small stream that feeds into the river, and are associated with patches of alluvial bottomland which may have been farmed utilizing small-scale gravity irrigation. Grinding stones, hammerstones, and adzes are commonly found around the habitation area or in refuse dumps downslope along the edge of the site. Three of the eight stelae at Tom-31 were found in close association with one of the house foundations (Figure 3). In some other sites, stelae were found away from the houses, on the edge of the habitation area. The three stelae found at the Tom- 8 site were probably not in their exact original location, for there has been a lot of destruction of the archaeological deposit due to modern village activities. However, all three Tom- 8 stelae were found close to rock foundations of rectangular shape, and the entire site has an extremely dense cover of domestic trash.

The SB-1 stela was found near low platforms, apparently for supporting houses, and in general association with quantities of domestic pottery sherds and oyster shell debris.

In contrast to the Tomatlan and San Blas stelae, all 29 Puerto Vallarta stelae were found in contexts which could be interpreted to be ceremonial - there are architectural features closely associated or at least nearby which do not seem to be domestic. The six PV-1 (Ixtapa) stelae appear to have originally been situated out in front of a $2.6 \mathrm{~m}$ high ceremonial mound. Excavation on the top of this mound in 1990 revealed a structure which appears to have been an altar. Two burials of the remains of cremated infants, plus eight pottery vessels, five of which contained bones of cremated infants, were found on the periphery of the altar. The PV-12 stelae were found inside a large rectangular structure $35 \mathrm{~m}$ from a mound which according to an informant contained jars with skulls and some blue stone pendants inside. The upper half of the PV-15 stela was found at the base of a $2.4 \mathrm{~m}$ high ceremonial mound, and the lower half of the stela was found in the adjacent plaza. The 20 PV-16 (La Soledad) stelae were found scattered about the surface of a plaza $20 \mathrm{~m}$ long by $10 \mathrm{~m}$ wide, situated adjacent to a cluster of three apparently ceremonial mounds. Three of these stelae are reported by a local farmer to have been standing as late as 1972 .

On the basis of artifact samples obtained from the surface of the sites (Appendix) and in some instances the architectural features, plus the data from the excavation of one of the houses (no. 1 at the Tom-31 site) (Figure 3), it seems that most if not all Tomatlan area stelae pertain to the Late Postclassic (Nahuapa) phase occupation of the valley, believed to date within the span A.D. 1000 to the A.D. 1500s (Mountjoy 1982, 1983). It is possible, however, that the stelae at one site (Tom-8) could pertain to the Early Postclassic (Aztatlan, A.D. 800-1000) phase at that site because both Postclassic phases are strongly represented at that site. At an overwhelmingly Aztatlan phase site (Tom-28) adjacent to Tom-8, a large disk-shaped stone altar was found near a ceremonial mound that covered an urn burial, but there was no stela associated with the altar.

As for the SB-1 stela, 96\% of the 50 decorated pottery sherds collected from the surrounding area are of the local Late Postclassic (Santa Cruz) phase (Appendix), the latest prehispanic phase in the San Blas area (Mountjoy 1970), believed to date within the range A.D. 1100 to the A.D. 1500s.

Based on the style of the pottery offerings recovered in the excavations conducted on the top of Mound 2 at the PV-1 (Ixtapa) site in 1990, the six stelae associated with the mound probably date to the early part of the Late Postclassic. The high percentage (83\%; Appendix) of Early Postclassic (Aztatlan phase) sherds recovered from the surface of the mound appears due to the use of earth containing mostly Early Postclassic sherds as fill for the construction of the Late Postclassic mound. One carbon sample from an Early Postclassic (Aztatlan phase) deposit at the PV-1 site has been radiocarbon dated to between A.D. 1070 and A.D. 1230 (Mountjoy 1990). The stelae presumably date somewhat later. At the other Puerto Vallarta sites where stelae have been found, surface collecting at PV-12 recovered 100\% Early Postclassic (Aztatlan) decorated sherds, but this is not very reliable since it is based on only three decorated sherds. Surface collecting at PV-15 in the area of the ceremonial mounds and the stela yielded 56 ${ }^{\circ}$ o Late Postclassic sherds and $44 \%$ Early Postclassic sherds, and the surface of the PV-16 site yielded 95\% Late Postclassic sherds.

\section{Function}

What may be inferred about the function of these 48 stones on the basis of the archaeological data? The stelae from the Puerto Vallarta area Ixtapa site are found in a context which is definitely ceremonial-in front of a mound supporting an altar surrounded by cremated infant remains and pottery offerings. The stelae at the Puerto Vallarta area La Soledad site are also in a ceremonial context, but the high number concentrated in a plaza is unusual, and hard to interpret. The stelae at the other Puerto Vallarta sites (Los Cimientos, and La Mesa del Huizcoyul) are also found in a context which appears to be ceremonial.

The data available at present suggest that stelae were introduced into Jalisco, and perhaps Navarit as well, at least as early 
as the beginning of the Late Postclassic. Because of the strong central Mesoamerican ties of the Early Postclassic Aztatlan culture, it is tempting to believe that the practice of stela erection was initially involved in the Aztatlan expansion. However, there is only meager support for that idea in the field data accumulated up to this point. Nevertheless, the earliest stelae probably represent the expansion of the common Mesoamerican cultural pattern in which stelae played a ritual role in ceremonial centers. But this original function of stelae was probably altered in the process of the adoption of stela erection in domestic settings by some west Mexican societies, although the stelae themselves continued to have a ceremonial function.

One major clue to the function of at least some of the Late Postclassic stelae comes from the analysis of 339 boulders with petroglyphs recorded in the Tomatlan area (Mountjoy 1987b). There is substantial evidence supporting the idea that the small pit, large pit, circle, bulls eye, circle with rays, spiral, and the anthropomorphic stick figures on those boulders are all various ways of depicting the sun god -its eye, face, or whole bodyand that many of the petroglyphs were pecked in an attempt to secure from the sun god the rains of the summer-fall wet season (Mountjoy 1984, 1987b). Virtually all of the petroglyphs on the Tomatlan stelae are sun symbols of one sort or another. Since so many of the Tomatlan stelae appear to have been freestanding within or on the edge of hamlets or villages of agriculturalists, some of them may have functioned as rustic sun dials which through the length and direction of the shadow cast could have been useful for tracing daylight time as well as the passage of the seasons. Two stelae could have been used for seasonal calculations by spacing them at such a distance that the shadow of one stone would reach the other during its maximum noontime extension of December 21st; the minimum noontime shadow extension would occur on June 21st (Jerry Meisner, personal communication, 1987). Perhaps the accuracy of shadow marking was increased by using stones pointed at the top.

The stela from the SB-1 site in Nayarit may have functioned in the same way. The spiral petroglyphs on the stone may be sun symbols, as they appear to be in the Tomatlan, Jalisco, area, or they may stand more directly for water (Mountjoy 1974, 1987a). The anthropomorphic head with horns near the top of the stone may either represent a shaman who engaged in rain-making rituals, or be another variation for representing the sun god (Mountjoy 1984, 1987b). Something such as an offertory bowl could have been placed on the flat top of this stone.

\section{OTHER POSSIBLE WEST MEXICAN STELAE}

Stones in some aspects similar to the 48 stelae reported here from Jalisco and Nayarit have been found at a few other sites in western and northwestern Mexico, or are present in some museum and private collections (Williams 1988). The northwestern limit of their distribution within Mesoamerica is found at Zape, Durango, about $75 \mathrm{~km}$ south of the Chihuahua border. The Zape stones were reported by J. Ramirez in 1604. An abstract of his report was published by Perez de Ribas (1645), in which it is said that on the peñol at Zape could be found idols which Ramirez attributed to the Mexicans, who were believed to have carried an idol with them in their wanderings. Hewett provides another account of these Zape idols:
In this region, not many miles from the present town of Zape, one cncounters for the first time in southward bound exploration, stone monuments that begin to forecast the monumental remains of the Mexican plateau. These consist of small monoliths of from 1 to 4 feet in height, some anthropomorphic, some of phallic motive. As they arc set in the vallcys, or at least allowed to remain there by the present farmers who regard them with superstitious respect, one suspects a conncction with the fructification and growth ceremonials. The Indians neither affirm nor deny this significance. (Hewett 1936:59)

Very crude stone figures, all less than $60 \mathrm{~cm}$ in height, have been found in the Callon Molino area of central Durango (Figure 1, Ganot and Peschard 1985), and Cabrero G. (1984) reported finding a vertical stone slab in the doorway of a rectangular house structure at the La Florida site near Valparaiso in southwestern Zacatecas (Figure 1). But the stones from these two locations do not appear very similar to the stelae found in the Tomatlan, Puerto Vallarta, and San Blas areas. There is also a report by Hrdlicka on the site of Banco de las Casas, Zacatecas (Figure 1), some $11 \mathrm{~km}$ south of Totoate, in which he mentioned finding "a number of oblong conical stones without markings, some of which stood upright in the ground, apparently as originally planted ..." (Hrdlicka 1903:396).

From Tiristaran Michoacan, in the northeastern corner of the state (Figure 1), there is a report of about 100 stone statues with anthropomorphic features, $50 \mathrm{~cm}$ to $100 \mathrm{~cm}$ in height, which originally were planted in the ground around two circular altars. Associated pottery is reported to be Classic or Postclassic (Corona 1970).

For Jalisco, there is one uniquely shaped stela at the Museum of Guadalajara which was reported to Otto Schöndube to have been found on the north side of the Banderas valley near the town of San Juan de Abajo. This stela is of a bluish slatelike stone. It has a pointed base which widens to a maximum of $0.49 \mathrm{~m}$ at the central part, and the upper half has been pecked into the form of a heron. This stela measures $1.71 \mathrm{~m}$ high and has a triangular cross-section of $0.08 \mathrm{~m}$ maximum thickness.

Also, Schöndube (1973-1974) reported 17 objects of sculpted stone, all but one with anthropomorphic features, found in the extreme southern part of the state near Tuxpan (Figure 1). Most are quite small, none being over $70 \mathrm{~cm}$ high; one of them (Schöndube 1973-1974:Lámina 97,3) is quite similar to the statues found at Tiristaran Michoacan. Pares Arias (1963) reported on what he calls "quarry stone stelae" from the extreme south of Jalisco. However, the stones which he illustrated are small square stone blocks with carvings on one face, representing Tlaloc in one case and perhaps Quetzalcoatl Ehecatl in another. Pares' designation of thesc square blocks as stelae appears inappropriate.

In Nayarit, apart from the SB-1 stela the only other stelalike archaeological find of which I am aware is a feature on a ceramic temple model excavated from a grave at the Amapa site (Figure I; Meighan 1976:41-43; Plate 12). This model has a round temple with a roof ornament, and the temple sits on top of a two-stage stepped rectangular platform. A stairway extends from the base of the platform up to the front door of the temple. In front of the temple doorway, almost filling its width but only filling about a third of its height, is a square slab, painted white and lacking designs. Meighan (1976:42) suggested that 
this feature may represent a stela, a screen, or an altar. The form of the piece seems to me very much like that of a rectangular stela, and it is reminiscent of the stela in front of the temple doorway at the Aztec site of Santa Cecilia, Mexico (Kelly 1982:74). Site context and obsidian hydration measurements suggest to Meighan that the temple model dates within the period A.D. 1200-1300.

South of Culiacan, Sinaloa (Figure 1), Ortiz de Zárte (1976:205) reported a stela-like stone with crude anthropomorphic features. Also in Sinaloa, between Mazatlan and Culiacan (Figure 1), Sauer and Brand (1932:28) reported finding sculptures of volcanic stone, about $60 \mathrm{~cm}$ to $90 \mathrm{~cm}$ high, which had been ground to a lozenge or cylindrical shape and then the facial features and limbs rudely outlined. Spirals and circles were found on the bodies of at least two of the idols. Sauer and Brand suggested that these stone figures were virtually identical to a stone figure Diguet (1903:19; Plate 3) illustrated from Cocolan (Cocula) in the central highlands of Jalisco (Figure 1), and which Diguet identified as a representation of a deity called Teopilzintli (teotl god, pilzintli infant) which was the principal deity of indigenous peoples in a large area of Jalisco and Nayarit.

This Teopilzintli "idol" is quite similar to several of the eight stone idols Lumholtz (1902 11:338-339) illustrated from the Tuxpan area of southern Jalisco (Figure 1), most of which measure close to but not higher than $50 \mathrm{~cm}$. Teopilzintli was identified by Schöndube (1972:361) as a sun god, and Schöndube cited Tello $(1891: 24,104)$ as reporting that this god was a child who guided (Mexica) groups from Aztatlan; a god that did not require human sacrifices but which in one instance is represented as a warrior. This same god was mentioned by Arias de Sabedra in 1673 (Arias de Sabedra 1899:18-27; McCarty and Matson 1975) as a Cora deity who had his seat in the east, and that the rising of the Pyltzintli sun on March 21, September 21, and December 21, awakened in turn the other three gods who held dominion over fall, winter, and spring, and the produce associated with each of these seasons. This account by Arias de Sabedra also clearly indicated the relation of the god Pyltzintli to a calendar based on solar observations made along the horizon, some of the sighting points being marked by statues and forms of stone.

\section{ETHNOHISTORIC DATA RELATING TO WEST MEXICAN STELAE}

There are other early Spanish accounts of stone-idol worship in northwestern Mesoamerica that are relevant to the interpretation of stelae which can be attributed to the Late Postclassic phase. One of these accounts, published in 1754, mentions the worship of idols among Huichol-Cora people in the Sierra Madre Occidental area of Jalisco and Nayarit (Ortega 1944). Ortega mentioned three primary deities which were the most powerful and commonly worshipped. Two of these, "Father of the Living" and "Our Mother," were of white stone, the first of a single stone and the second consisting of two stones (Ortega 1944:19). The first idol, cited as the foremost deity, was believed to have been made by the sun, and the spirit of the sun was said to reside within its body. Ortega mentioned many other minor idols which were also worshipped, some of which he describes as small boulders or cobblestones. About these, Ortega related the following:
It would bc impossible to calculate the exact number of this multitude of little idols, because therc would hardly bc a hill in almost half of this province that I have not inspected for one reason or another and on which I havc not stumbled onto these infernal statuettes: some seem forgotten in a state of disrepair with uncleaned courtyards; many arc well cared for, and the placcs in which they are worshipped are very clcan. And although tcmples are not made for them, an enclosure has been made with rocks stuck into the ground, the idol being placed in the center, and taking care that the area within the circle be always swcpt clean. They would do the same thing in high nooks and crannies of the rivers, where they would place similar deities, in order to have this resource closcr at hand when they wanted an abundant catch of fish. In a distance of barely eighteen leagues of only one of thc many rivers which flow through these mountains there were fourteen of these idols, which today lie buried and completely forgotten. (Ortega 1944:21; my translation)

Other accounts which are relevant for the interpretation of the stelae come from descriptions of the Acaxee culture of Sinaloa and Durango which was centered about the headwaters of the Culiacan river at the time of the Spanish conquest (Spicer 1969). Beals' summary description of Acaxee culture included a lengthy section of their idol worship which was drawn from documents dated around A.D. 1600 (Beals 1933:22-27). He said their idols were often of stone and might be painted with features, carved, or both carved and painted. Frequently the Acaxee idols were in the form of persons, although some are mentioned in the form of birds, deer, rabbits, turtles, and snakes. According to Beals, some idols appear to represent a pantheon, although many were personal idols that could be inherited. At least one idol performed a divinatory function for a whole community, giving out information on cause of death, method for revenge, and success in warfare. Some of the Acaxee idols were connected with warfare, but others were related to agriculture, fishing, hunting, rain-making, and curing.

\section{CONCLUSION}

In the archaeological literature, the northwestern boundary of stela distribution is generally stated to be along the GuerreroMichoacan border. However, this is actually the limit only of rather tall stelae that are well shaped (generally rectangular), and pecked or carved in such a fashion that the designs stand out in low relief. Southeast of this border such stone monuments, as well as many smaller and cruder stone monuments, some of which lack carved or pecked designs, are usually referred to as stelae in the archaeological literature. But northwest of the Guerrero-Michoacan border, the generally cruder and less well-shaped stone monuments, some of which have designs pecked into the stone, are referred to in the archaeological literature as idols or statues. It is argued here that even though they are generally more rustic and smaller than the stelae found in heartland Mesoamerica, many of these stone monuments from northwestern Mesoamerica should be called stelae.

The field evidence relating to stelae from sites in the Tomatlan, Jalisco, Puerto Vallarta, Jalisco, and San Blas, Nayarit, areas indicates that all of these west Mexican stelae date to the Postclassic, and those found so far probably all date to the Late phase of the Postclassic. This means that the practice of erect- 
ing stelae in peripheral northwestern Mesoamerica was flourishing to some degree after the practice of stela erection was severely curtailed if not abandoned in many areas of the Mesoamerican heartland.

Insofar as some west Mexican stelae have pecked sun-symbol designs, and some may have been utilized for solar observations or calculations, they can be linked to the astronomical association of stela raising and inscribing in other parts of Mesoamerica, such as the Maya site of Copan (Aveni 1977). Also, the anthropomorphic designs of some west Mexican stelae appear to represent a god (apparently the sun), as is sometimes the case with stelae in the Mexican area of the Mesoamerican heartland which have carvings of deities such as the rain god Tlaloc. The association of cremated infant remains with the stelae at the PV-I site could be construed to lend some further support to the association of the west Mexican stelae with the sun god. At least in Tarascan society in Michoacan there was a link between the practice of cremation of their ruler the Cazontzi and the sun god Curicaueri (the maximum fire deity) who the Cazontzi represented on earth (Corona Núñez 1946).

In central Mesoamerica the presence and number of stelae appears to relate in direct proportion to the sociopolitical status of certain centers (Marcus 1973). This seems to be the case in regard to the stelae found in the Puerto Vallarta area at the PV-1 (Ixtapa) site, which appears to be the major Postclassic center on the southern side of the Banderas valley. On the other hand, if the other three Puerto Vallarta area sites with stelae were ceremonial centers, they were definitely minor centers in comparison with Ixtapa, even though one of them had far more stelae.

In contrast, the stelae of the Tomatlan, Jalisco, and San Blas, Nayarit, areas are associated with what appear to be nonelite domestic remains. They are found in remote hamlet-sized settlements as well as in large villages. Their context in sites of either size in most cases appears to be non-temple and nonceremonial centered. Also, there are no ethnohistorical data to suggest that by European contact times these west Mexican stone monuments served a commemorative or historical function, as they often did in Classic Maya culture.

As for the practice of stela erection, the west Mexican monuments are a component of a continuing process of mesoamericanization of the area during the Postclassic period. This process appears to have involved the transmission of foriegn ceremonial practices in the early part of the Late Postclassic, which in some areas were reworked or adapted to the exigencies of native west Mexican societies in which considerations of status, power, and history were of less importance than idol worship, especially as it related to the water-giving sun god.

\section{SUMARIO}

El proceso de la expansion de la cultura mesoamericana al occidente y noroeste de México ha sido un terra de especulación e investigación durante más dc tres siglos. Aunque varios rasgos culturales mcsoamericanos han sido señalados como parte de estc proceso, Ia costumbre de erigir estelas no ha sido uno de estos rasgos. Investigaciones de campo llevadas a cabo por el autor en los estados de Jalisco y Nayarit durantc los últimos 14 años han resultado cn el hallazgo de 48 monumentos de piedra que aqui se proponcn scr versiones rústicas de las estelas, generalmente más sofisticadas, que están asociadas con las culturas de Mesoamérica central. Se describen estas estelas del occidente, y se discute su contexto, fecha, y posible función. Además, se describen otros monumentos similares de piedra de otros sitios en el occidentc y noroeste de México, y se presentan algunos datos etnohistóricos pertinentes a su interpretación. Por Ultimo, se di5cute Ia costumbre de erigir estelas en relación al proccso de la mesoamericanización del occidente y noroeste de Mexico.

\section{ACKNOWLEDGMENTS}

This artiele is based on data gathered in the municipalities of Tomatlan, Jalisco, Puerto Vallarta, Jalisco, and San Blas, Nayarit, during field research supported by the Mexican Secretariat of Agrieulturc and Water Resources, a Fulbright grant (1030212) from the United States Government, a grant from the Wenner-Gren Foundation for Anthropological Research, and grants from the University of North CarolinaGreensboro Graduate Research Council. The fieldwork was conducted under permits granted by the Mexican Institute of Anthropology and History, and with the cooperation of the I.N.A.H. Regional Center in

\section{REFERENCES}

Arias de Sabedra, Antonio

1899 Información rendida por el P. Antonio Arias y Saavedra, acerca del estado de la sierra del Nayarit, en el siglo XVII. In Nayarit: Colección de documentos inéditos, históricos y et nográficos, acerca de la sierra de ese nombre, edited by Alberto Santoscoy, pp. 7-35. Guadalajara.

Armillas, Pedro

1964 Condiciones ambientales y movimientos de pueblos en la frontera septentrional de Mesoamérica. In Homenaje a Fernando Mdrquez-Miranda, pp. 62-82. Publicaciones del Seminario de Estudios Americanistas y Seminario de Antropologia Americana, Universidades de Madrid y Sevilla, Madrid.
Guadalajara. I cspecially want to acknowledge the aid of J. Charles Kelley and Otto Schöndube. J. Charles provided several research leads which proved fruitful. Otto provided access to and information on the San Juan de Abajo stela, and it was he who discovered the stela illustrated in Figure 5 while we were recording the PV-15 site. This article is a revised and expanded version of papers presented in 1985 at the Annual Meeting of the Society of American Archaeology in Denver and at the Round Table meeting of the Sociedad Mexicana de Antropologia in Queretaro.

Aveni, Anthony F.

1977 Concepts of Positional Astronomy Employed in Ancient Mesoamerican Architecturc. In Native American Astronomy, edited by A. Aveni, pp. 3-19. University of Texas Press, Austin.

Aveni, Anthony F., H. Hartung, and J.C. Kelley

1982 Alta Vista (Chalchihuites): Astronomical Implications of a Mesoamerican Ceremonial Outpost at the Tropic of Cancer. American Antiquity 47:316-335.

Batres, Leopold

1903 Visita a los monumentos arqueológicos de "La Quemada," Zacatecas. Viuda de Francisco Diaz de Lean, Mexico. 
Beals, Ralph L.

1933 The Acaxee: A Mountain Tribe of Durango and Sinaloa. Ibero-Americana 6. University of California Press, Berkeley. Brand, Donald D.

1939 Notes on the Geography and Archaeology of Zape, Durango. In So Live the Works of Men, edited by D. Brand and F.E. Harvey, pp. 75-105. University of New Mexico Press, Albuquerque.

Brockington, Donald L.

1957 Piedra Parada: A Comparative Study of a Site in Jamiltepec, Oaxaca. M.A. thesis, Mexico City College, Mexico.

Bullard, William R., Jr.

1970 Topoxte, A Postclassic Site in Petcn, Guatemala. In Monographs, and Papers in Maya Archaeology, edited by W.R. Bullard, Papers of the Peabody Museum of American Archaeology and Ethnology, vol. 61. Harvard University, Cambridgc, MA.

Cabrero G., Maria Teresa

1984 Civilización en el norte de Mexico. Instituto de Investigaciones Antropológicas, Seric Antropológica, 103. Universidad Autónoma de México.

Cervantes, Maria Antonieta

1976 La estela de Alvardo. Actas del XLI Congreso Internacional de Americanistas 2:309-322.

Chadwick, Robert

1971 Archaeological Synthesis of Michoacan and Adjacent Regions. In Handbook of Middle American Indians, vol. 11, edited by G. Ekholm and I. Bernal, pp. 657-693. University of Texas Press, Austin.

Corona Núñez, José

1946 La religion de los tarascos. In Anales del Museo Michoacano, Número 4, Segunda Epoca, pp. 13-38. Morelia.

Corona S., Eduardo

1970 Hallazgo arqueológico en Tiristarán. LN.A.H. Boleti', 42:3133, México.

Diguet, Leon

1903 Contribution á l'ethnographie précolombicnne du Méxique. Le Chimalhuacan et ses populations avant la conquête espagnole. Journal Societe des Américanistes de Paris 1-57.

Diaz 0., Clara

$1986 \mathrm{La}$ presencia teotihuacana en las estelas de Tepecuacuilco. In Arqueología y etnohistoria del estado de Guerrero, pp. 203-208. Instituto Nacional de Antropologia e Historia y Gobierno del Estado de Guerrcro.

Ekholm, Gordon F.

1940 The Archaeology of Northwestern and Wcstern Mexieo. In The Maya and Their Neighbors, edited by C.L. Hay, R.L. Linton, S.K. Lothrop, H.L. Shapiro, and G. Vaillant, pp. 320-330. Applcton-Century, New York and London.

1941 Tula and Northwestern Mexico. Revista Mexicana de Estudios Antropológicos 5:193-198.

1942 Excavations at Guasave, Sinaloa, Mexico. Anthropological

Papers of the American Museum of Natural History 38:23-139.

Gamio, Lorenzo

1963 Estela de Yaguila. IN.A.H. Boletín 12:11-13.

Gamio, Manuel

1910 Los monumentos arqueológicos de los immediaciones de Chalchihuites, Zacatecas. Anales del Museo Nacional de Mexico.

Ganot R., Jaime, and A. Peschard F.

1985 La cultura Aztatkán: Frontera del occidente y norte de mesoamérica en el postclásico. Paper presented at the XIX Mcsa Redonda of the Sociedad Mexicana de Antropologia, Querétaro, Mexico.

Grove, David C.

1989 Chalcatzingo and Its Olmec Connection. In Regional Perspectives on the Olmec, edited by R. Sharer and D. Grove, pp. 122147. Cambridgc University Press, Cambridge.

Grove, David C., and L.I. Paradis

1971 An Olmec Stela from San Miguel Amuco, Guerrero. American Antiquity 36:95-102.

Hammond, Norman

1982 A Late Formative Period Stcla in the Maya Lowlands. American Antiquity 47:396-403.

Hewett, Edgar L.

1936 Ancient Life in Mexico and Central America. Bobbs-Merrill, Indianapolis and New York.
Hrdlicka, Alés

1903 The Rcgion of the Ancient "Chichimecs," with Notes on the Tepecanos and the Ruins of La Quemada, Mexico. American Anthropologist 5:385-440.

Jorrín, Maria

1974 Stone Monuments. In The Oaxacan Coastal Project, part 1, edited by D.L. Brockington, M. Jorrín, and J.R. Long. Vanderbilt University Publications in Anthropology 8, pp. 23-81. Vanderbilt University, Nashville.

Kelley, J. Charles

1974 Speculations on the Culture History of Northwestern Mesoamcrica. In The Archaeology of West Mexico, edited by B. Bell, pp. 19-39. Sociedad de Estudios Avanzados del Occidente de México, Ajijic, Jalisco.

Kelley, J. Charles, and E. Abbott

1966 The Cultural Sequence on the North Central Fronticr of Mesoamerica. Actas y memorias, 36avo Congreso Internacional de Americanistas 1:325-344.

Kclley, J. Charles, and E.A. Kelley

1976 Alta Vista: Outpost of Mesoamerican Empire on the Tropic of Cancer. Las fronteras de Mesoamérica 1:21-40. Sociedad Mexicana de Antropologia, Tegucigalpa.

Kclly, Isabel T.

1941 The Relationship Bctween Tula and Sinaloa. Revista Mexicana de Estudios Antropológicos 5:199-207.

1985 Some Gold and Silver Artifacts from Colima. In The Archaeology of West and Northwest Mexico, edited by M.S. Foster and P.C. Weigand, pp. 153-179. Westvicw Press, Boulder and London.

Kelly, Isabel T., and B. Braniff de Torres

1966 Una relación cerámica cntre Occidente y la Mesa Central. I.N.A.H. Boletín 23:26-27.

Kelly, Joyce

1982 The Complete Visitor's Guide to Mesoamerican Ruins. University of Oklahoma Press, Norman.

Kirchhoff, Paul

1943 Mesoamérica: sus limites geográficos, composición étnica y caractercs culturales. Acta Americana 1:92-107.

1948 Etnografia antigua. In El Occidente de Mexico, pp. 134-136. Sociedad Mexicana de Antropología, Mcxico.

Lister, Robert H.

1949 Excavations at Cojumatlan, Michoacan, Mexico. University of New Mcxico Publications in Anthropology 5. University of New Mexico, Albuquerque.

1971 Archaeological Synthesis of Guerrero. In Handbook of Middle American Indians, vol. 11, editcd by G. Elkholm and I. Bernal, pp. 619-631. University of Texas Press, Austin.

Lowe, Gareth W.

1989 The Heartland Olmec: Evolution of Material Culture. In Regional Perspectives on the Olmec, edited by R. Sharer and D. Grovc, pp. 33-67. Cambridge University Press, Cambridgc.

Lumholtz, Carl

1902 Unknown Mexico: A Record of Five Years' Exploration among the Tribes of the Western Sierra Madre in the Tierra Caliente of Tepic and Jalisco; and among the Tarascans of Michoacan, II. Rio Grande Press (1973 edition), Glorieta, New Mcxico.

McCarty, Kieran, and D. Matson

1975 Franciscan Report on the Indians of Nayarit, 1673. Ethnohistory 22(3):193-221.

Marcus, Joyce

1973 Territorial Organization of the Lowland Classic Maya. Science 180:911-916.

1976 Emblem and State in the Classic Maya Lowlands. Dumbarton Oaks, Washington, DC.

Marquina, Ignacio

1970 Proyecto Cholula. Instituto Nacional de Antropologia e Historia, Número 19. Mexico.

Martinez D., Guadalupe

1986 Teopantecuanitlan. In Arqueología y etnohistoria del estado de Guerrero. Instituto Nacional de Antropologia e Historia, Gobierno del Estado de Guerrero.

Mason, J. Alden

1937 Late Archaeological Sites in Durango, Mexico, from Chalchihuites to Zape. Publications of the Philadelphia Anthropological Society 1:127-146. 
Matos M., Eduardo, and I. Kelly

1974 Una vasija que sugicre relaciones entre Teotihuacán y Colima. In The Archaeology of West Mexico, edited by B. Bell, pp. 202205. Sociedad de Estudios Avanzados del Occidentc de México, Ajijic, Jalisco.

Meighan, Clement W.

1976 The Archaeology of Amapa, Nayarit. Monumenta Archaeologica 2. The Institute of Archaeology, University of California, Los Angeles.

Morley, Sylvanus G.

1956 The Ancient Maya. Third edition, revised by G.W. Brainerd. Stanford University Press.

Mountjoy, Joseph B.

1970 Prehispanic Culture History, and Cultural Contact on the Southern Coast of Nayarit, Mexico. Ph.D. dissertation, Southern Illinois University. Univcrsity Microfilms, Ann Arbor.

1974 Some Hypotheses Regarding the Petroglyphs of West Mexico. Mesoamerican Studies 9. Research Records of the University Museum, Southern Illinois University, Carbondale.

1982 El proyecto Tomatlán de salvamento arqueológico: fond ${ }^{\circ}$ etnohistórico y arqueológico, desarrollo del proyecto, estudios de la superficie. I.N.A.H. Colccción Cientifica: Arqueologia 122. Mexico.

1983 Investigaciones arqueológicas cn la cuenca del rio Tomatlán, Jalisco: 1975-1977. Pantoc 5:21-50. Universidad Autónoma de Guadalajara.

1984 Significado de dos documentos del siglo XVII en la interpretación de petroglifos encontrados en la cuenca del rio Tomatlán, Jalisco. Investigaciones Recientes En El Area Maya 4:487-494. Proceedings of the Mesa Redonda of the Soeiedad Mexicana de Antropología, San Cristóbal de las Casas, Chiapas.

1987a Antiquity, Interpretation, and Stylistic Evolution of Petroglyphs in West Mexico. American Antiquity 52:161-174.

1987b El proyecto Tomatlán de salvamento arqueológico: el arte rupestre. I.N.A.H. Colección Cientifica: Arqueología 163. Mexico.

1989 Proyecto arqueológico Valle de Banderas: segunda temporada. Report on file in the technical archives of the Instituto Nacional de Antropología e Historia, Mexico.

$1990 \mathrm{El}$ desarrollo de la cultura Aztatlán visto desdc su frontera suroestc. In Mesoamérica y norte de Mexico: siglo IX-XII, vol. 2, edited by Federica Sodi M., pp. 541-564. Museo Nacional de Antropología, Mexico.

Muller, Florcncia

1966 La estela del Coracero, Guerrero. In Summa antropológica en

homenaje a Roberto J. Weitlander, pp. 91-98. I.N.A.H., Mexico.

Noguera, Eduardo

1942 Exploraciones en El Opeño, Michoacán. Proceedings of the

27 avo Congreso Internacional de Americanistas 1:574-586.

Oliveros, Arturo

1974 Nuevas exploraciones en El Opeño Michoacan. In The Archaeology of West Mexico, edited by B. Bell, pp. 182-201. Sociedad de Estudios Avanzados del Occidente dc México. Ajijic, Jalisco.

Ortega, José

1944 Apostólicos afanes de la compañia de Jesus en su provincia de Mexico, libro Maravillosa reducción y conquista de la provincia de San Joseph del Gran Nayar, nuevo reino de Toledo. Editorial Layac, Mexico.

Ortiz de Zárate, Gonzálo

1976 Petroglifos de Sinaloa. Fomento Cultural Banamex, Mexico. Osborne, Douglas

1943 An Archaeological Reconnaissance in Southeastern Michoacan, Mexico. American Antiquity 9:59-73.

Pares Arias, José

1963 Esculturas y estelas liticas prehispánicas del sur del estado de Jalisco. Eco, Revista del Instituto Jalisciense de Antropología e Historia 16:3-4.

Pérez de Ribas, Andrés

1645 Historia de los triunfos de nuestra santa fe entre las gentes las mks bárbaras y fieras del Nuevo Orbe. Madrid.

Pickering, Robert B.

1974 A Preliminary Report on the Osteological Remains from Alta Vista, Zacatecas. In The Archaeology of West Mexico, edited by
B. Bell, pp. 240-248. Sociedad de Estudios Avanzados del Occidente de Mexico. Ajijic, Jalisco.

1985 Human Osteological Remains from Alta Vista, Zacatecas: An Analysis of the Isolated Bone. In The Archaeology of West and Northwest Mexico, edited by M.S. Foster and P.C. Weigand, pp. 289-325. Westview Press, Boulder and London.

Porter, Muriel

1956 Excavations at Chupicuaro, Guanajuato, Mexico. Transactions of the American Philosophical Society (new series) 46(5). Proskouriakoff, Tatiana

1950 A Study of Classic Maya Sculpture. Carnegie Institution of

Washington Publication 593. Washington, DC.

Random House Dictionary of the English Language

1966 Random House, New York.

Sáenz, César A.

1966a Exploraciones en El Ixtepete, Jalisco. I.N.A.H. Boletín 23:1418.

1966b Cabecitas y figurillas de barro del Ixtepete, Jalisco. I.N.A.H. Boletín 24:47-49.

1966c Exploraciones en Xochicalco. I.N.A.H. Boletín 26: 24-34. Sauer,

Carol 0., and D.D. Brand

1932 Aztatlan: Prehistoric Mexican Frontier on the Pacific Coast. IberoAmericana 1. University of California Press, Berkeley. Schöndube B., Otto

1972 La religion en el occidente de México. In Religión en Mesoamérica, XII Mesa Redonda de la Sociedad Mexicana de Antropología, pp. 357-363. Mexico.

1973-1974 Tamazula-Tuxpan-Zapotlán: Pueblos de la frontera septentrional de ía antigua Colima. Professional thesis, Escuela Nacional de Antropología e Historia, Mexico.

1974 Deidades prehispánicas en el arca de Tamazula-Tuxpan Zapotlán en el estado de Jalisco. In The Archaeology of West Mexico, editcd by B. Bell, pp. 168-181. Sociedad de Estudios Avanzados del Oceidente de México, Ajijic, Jalisco.

1980 Epoca prehispánica. In Historia de Jalisco, editcd by José Maria Muria, pp. 111-258. Gobierno de Jalisco Secretaria General Unidad Editorial, Guadalajara.

Spicer, Edward H.

1969 Northwest Mexico: Introduction. In Handbook of Middle American Indians, vol. 8, edited by Evon G. Vogt, pp. 777-791. University of Texas Press, Austin.

Tello, Antonio

1891 Crónica miscelánea en que se data de la conquista espiritual y temporal de la Santa Provincia de Xalisco en el Nuevo Reino de Galicia y Vizcaya y descubrimientos de Nuevo México. Imprenta La República Literaria, Guadalajara.

1968 Crónica miscelánea de la Sancta Provincia de Xalisco, Libro vol. 1.

Instituto Jalisciense de Antropología $e$ Historia, Guadalajara. Trombold,

Charles D.

1985 A Summary of the Archacology in the La Quemada Region. In The Archaeology of West and Northwest Mexico, edited by M.S. Foster and P.C. Weigand, pp. 237-267. Westview Press, Boulder and London.

Webster's Third New International Dictionary of the English Language

(unabridged)

1966 G.C. Merriam, Springfield, MA.

Weigand, Phil C.

1974 The Ahualulco Site and the Shaft-Tomb Complex of the Etzatlán Area. In The Archaeology of West Mexico, edited by B. Bell, pp. 120131. Sociedad de Estudios Avanzados del Occidente de México, Ajijic, Jalisco.

1978 The Prehistory of the State of Zacatecas: An Interpretation, Part 1 and Part 2. Anthropology 2(1):67-87; 1(2)103-117.

1985 Evidence for Complcx Societies during the Western Mesoamerican Classic Period. In The Archaeology of West and Northwest Mexico, edited by M.S. Foster and P.C. Weigand, pp. 47-91. Westview Press, Boulder and London.

Williams, Eduardo 1988 The Stone Sculpture of Ancient West Mexico: Analysis and Classification. Ph.D. dissertation, University of London.

von Winning, Hasso

1979 Dos estelas en la Mixteca Baja del sur de Puebla. Anales del Instituto de Investigaciones Estéticas 13(4):13-22. 


\section{APPENDIX}

Stelae from the municipalities of Tomatlan, Jalisco, and San Blas, Nayarit

\begin{tabular}{|c|c|c|c|c|c|c|c|c|c|c|}
\hline Site & Stela & Whole & Height & Width & Thickness & Form & Rock & Glyphs & Context & Phase $(\%)$ \\
\hline Tom-8 & $\begin{array}{l}1 \\
2 \\
3\end{array}$ & $\begin{array}{l}\text { yes } \\
\text { yes } \\
\text { yes }\end{array}$ & $\begin{array}{l}1.20 \mathrm{~m} \\
1.25 \mathrm{~m} \\
1.73 \mathrm{~m}\end{array}$ & $\begin{array}{l}0.40 \mathrm{~m} \\
0.48 \mathrm{~m} \\
0.35 \mathrm{~m}\end{array}$ & $\begin{array}{l}0.28 \mathrm{~m} \\
(?) \\
0.25 \mathrm{~m}\end{array}$ & $\begin{array}{l}\text { oblong, pointed, } \nabla \text {-section } \\
\text { rect., pointed } \\
\text { rect., pointed, O-section }\end{array}$ & $\begin{array}{l}\text { grano-diorite } \\
\text { grano-diorite } \\
\text { grano-diorite }\end{array}$ & $\begin{array}{l}\text { yes } \\
\text { no } \\
\text { no }\end{array}$ & $\begin{array}{l}\text { domestic area } \\
\text { domestic area } \\
\text { domestic area }\end{array}$ & $\begin{array}{l}\text { L. Postclassic (68) } \\
\text { L. Postclassic (68) } \\
\text { L. Postclassic (68) }\end{array}$ \\
\hline Tom-13 & $\begin{array}{l}1 \\
2\end{array}$ & $\begin{array}{l}\text { yes } \\
\text { yes }\end{array}$ & $\begin{array}{l}1.50 \mathrm{~m} \\
(?)\end{array}$ & $\begin{array}{c}0.35 \mathrm{~m} \\
(?)\end{array}$ & $\begin{array}{l}(?) \\
(?)\end{array}$ & $\begin{array}{l}\text { rect., pointed, } \nabla \text {-section } \\
\text { rect., pointed, } \nabla \text {-section }\end{array}$ & $\begin{array}{l}\text { grano-diorite } \\
\text { grano-diorite }\end{array}$ & $\begin{array}{l}\text { no } \\
\text { no }\end{array}$ & $\begin{array}{l}\text { domestic area } \\
\text { domestic area }\end{array}$ & $\begin{array}{l}\text { L. Postclassic }(100) \\
\text { L. Postclassic (100) }\end{array}$ \\
\hline Tom-31 & $\begin{array}{l}1 \\
2 \\
3 \\
4\end{array}$ & $\begin{array}{l}\text { yes } \\
\text { yes } \\
\text { yes } \\
\text { no }\end{array}$ & $\begin{array}{l}2.34 \mathrm{~m} \\
2.10 \mathrm{~m} \\
1.85 \mathrm{~m} \\
1.51 \mathrm{~m}\end{array}$ & $\begin{array}{l}0.60 \mathrm{~m} \\
0.52 \mathrm{~m} \\
0.41 \mathrm{~m} \\
0.72 \mathrm{~m}\end{array}$ & $\begin{array}{l}0.12 \mathrm{~m} \\
0.19 \mathrm{~m} \\
0.09 \mathrm{~m} \\
0.16 \mathrm{~m}\end{array}$ & $\begin{array}{l}\text { losenge, pointed, } 0 \text {-section } \\
\text { rect., pointed, } \square \text {-section } \\
\text { rect., pointed, } \square \text {-section } \\
\text { trapezoid, } \square \text {-section }\end{array}$ & $\begin{array}{l}\text { grano-diorite } \\
\text { grano-diorite } \\
\text { grano-diorite } \\
\text { grano-diorite }\end{array}$ & $\begin{array}{l}\text { no } \\
\text { no } \\
\text { no } \\
\text { yes }\end{array}$ & $\begin{array}{l}\text { domestic area } \\
\text { domestic area } \\
\text { domestic area } \\
\text { domestic area }\end{array}$ & $\begin{array}{l}\text { L. Postclassic (80) } \\
\text { L. Postclassic (80) } \\
\text { L. Postclassic (80) } \\
\text { L. Postclassic (80) }\end{array}$ \\
\hline & $\begin{array}{l}5 \\
6 \\
7 \\
8\end{array}$ & $\begin{array}{l}\text { yes } \\
\text { no } \\
\text { no } \\
\text { no }\end{array}$ & $\begin{array}{l}1.98 \mathrm{~m} \\
(1.19 \mathrm{~m}) \\
(1.40 \mathrm{~m}) \\
(0.46 \mathrm{~m})\end{array}$ & $\begin{array}{l}0.52 \mathrm{~m} \\
0.86 \mathrm{~m} \\
0.67 \mathrm{~m} \\
0.59 \mathrm{~m}\end{array}$ & $\begin{array}{l}0.25 \mathrm{~m} \\
0.12 \mathrm{~m} \\
0.09 \mathrm{~m} \\
0.12 \mathrm{~m}\end{array}$ & $\begin{array}{l}\text { rect., pointed, } \square \text {-section } \\
\text { rect., pointed, } \square \text {-section } \\
\text { rect., } \square \text {-section } \\
\text { rect., } \square \text {-section }\end{array}$ & $\begin{array}{l}\text { grano-diorite } \\
\text { grano-diorite } \\
\text { grano-diorite } \\
\text { grano-diorite }\end{array}$ & $\begin{array}{l}\text { no } \\
\text { no } \\
\text { no } \\
\text { yes }\end{array}$ & $\begin{array}{l}\text { domestic area } \\
\text { domestic area } \\
\text { domestic area } \\
\text { domestic area }\end{array}$ & $\begin{array}{l}\text { L. Postclassic (80) } \\
\text { L. Postclassic (80) } \\
\text { L. Postclassic (80) } \\
\text { L. Postclassic (80) }\end{array}$ \\
\hline Tom-52 & 1 & yes & $1.25 \mathrm{~m}$ & $0.44 \mathrm{~m}$ & $0.10 \mathrm{~m}$ & rect., pointed, $\square$-section & grano-diorite & no & top of hill & L. Postclassic (?) \\
\hline Tom-56 & $\begin{array}{l}1 \\
2\end{array}$ & $\begin{array}{l}\text { yes } \\
\text { yes }\end{array}$ & $\begin{array}{l}1.40 \mathrm{~m} \\
1.00 \mathrm{~m}\end{array}$ & $\begin{array}{l}0.25 \mathrm{~m} \\
0.22 \mathrm{~m}\end{array}$ & $\begin{array}{l}0.14 \mathrm{~m} \\
0.16 \mathrm{~m}\end{array}$ & $\begin{array}{l}\text { rect., pointed, } \square \text {-section } \\
\text { oblong, pointed, } 0 \text {-section }\end{array}$ & $\begin{array}{l}\text { diorite } \\
\text { grano-diorite }\end{array}$ & $\begin{array}{l}\text { no } \\
\text { no }\end{array}$ & $\begin{array}{l}\text { edge domestic area } \\
\text { edge domestic area }\end{array}$ & $\begin{array}{l}\text { L. Postclassic (?) } \\
\text { L. Postclassic (?) }\end{array}$ \\
\hline Tom-57 & 1 & yes & $1.10 \mathrm{~m}$ & $0.21 \mathrm{~m}$ & $0.10 \mathrm{~m}$ & cylind., pointed, O-section & diorite & no & edge domestic area & L. Postclassic (?) \\
\hline Tom-62 & 1 & no & $(0.83 \mathrm{~m})$ & $0.22 \mathrm{~m}$ & $0.10 \mathrm{~m}$ & cylind., pointed, O-section & grano-diorite & no & edge domestic area & L. Postclassic (?) \\
\hline SB-1 & 1 & yes & $1.03 \mathrm{~m}$ & $0.36 \mathrm{~m}$ & $0.26 \mathrm{~m}$ & oblong, flat top, 0 -section & grano-diorite & yes & domestic area & L. Postclassic (96) \\
\hline
\end{tabular}


Stelae from the municipality of Puerto Vallarta

\begin{tabular}{|c|c|c|c|c|c|c|c|c|c|c|}
\hline Site & Stela & Whole & Height & Width & Thickness & Form & Rock & Glyphs & Context & Phase $(\%)$ \\
\hline \multirow[t]{6}{*}{ PV-1 } & 1 & no & $(1.20 \mathrm{~m})$ & $0.40 \mathrm{~m}$ & $0.26 \mathrm{~m}$ & rect., $\square$-section & rhyolite & no & ceremonial ctr. & E. Postclassic (83) \\
\hline & 2 & yes & $1.12 \mathrm{~m}$ & $0.35 \mathrm{~m}$ & $0.21 \mathrm{~m}$ & rect., pointed, $\nabla$-section & rhyolite & no & ceremonial ctr. & E. Postclassic (83) \\
\hline & 3 & no & $(0.52 \mathrm{~m})$ & $0.36 \mathrm{~m}$ & $0.25 \mathrm{~m}$ & rect., pointed, $\square$-section & granite & no & ceremonial ctr. & E. Postclassic (83) \\
\hline & 4 & yes & $0.96 \mathrm{~m}$ & $0.36 \mathrm{~m}$ & $0.24 \mathrm{~m}$ & rect., pointed, $\nabla$-section & granite & no & ceremonial ctr. & E. Postclassic (83) \\
\hline & 5 & yes & $0.81 \mathrm{~m}$ & $0.28 \mathrm{~m}$ & $0.22 \mathrm{~m}$ & losenge, pointed, O-section & diorite & no & ceremonial ctr. & E. Postclassic (83) \\
\hline & 6 & yes & $0.84 \mathrm{~m}$ & $0.36 \mathrm{~m}$ & $0.32 \mathrm{~m}$ & rect., $\square$-section & granite & no & ceremonial ctr. & E. Postclassic (83) \\
\hline \multirow[t]{2}{*}{ PV-12 } & 1 & no & $(1.10 \mathrm{~m})$ & $0.36 \mathrm{~m}$ & $0.21 \mathrm{~m}$ & rect., pointed, $\square$-section & granite & no & ceremonial ctr. & E. Postclassic (100) \\
\hline & 2 & no & $(0.67 \mathrm{~m})$ & $0.30 \mathrm{~m}$ & $0.26 \mathrm{~m}$ & rect., pointed, O-section & granite & no & ceremonial ctr. & E. Postclassic (100) \\
\hline PV-15 & 1 & yes & $1.37 \mathrm{~m}$ & $0.27 \mathrm{~m}$ & $0.14 \mathrm{~m}$ & rect., pointed, $\square$-section & granite & no & ceremonial ctr. & L. Postclassic (56) \\
\hline \multirow[t]{20}{*}{ PV-16 } & 1 & no & $(0.90 \mathrm{~m})$ & $0.29 \mathrm{~m}$ & $0.15 \mathrm{~m}$ & rect., O-section & rhyolite & no & ceremonial ctr. & L. Postclassic (95) \\
\hline & 2 & yes & $1.42 \mathrm{~m}$ & $0.28 \mathrm{~m}$ & $0.23 \mathrm{~m}$ & rect., pointed, $\triangle$-section & rhyolite & no & ceremonial ctr. & L. Postclassic (95) \\
\hline & 3 & yes & $1.12 \mathrm{~m}$ & $0.34 \mathrm{~m}$ & $0.18 \mathrm{~m}$ & rect., pointed, $\square$-section & rhyolite & no & ceremonial ctr. & L. Postclassic (95) \\
\hline & 4 & yes & $0.82 \mathrm{~m}$ & $0.24 \mathrm{~m}$ & $0.13 \mathrm{~m}$ & rect., pointed, $\square$-section & granite & no & ceremonial ctr. & L. Postclassic (95) \\
\hline & 5 & yes & $1.30 \mathrm{~m}$ & $0.20 \mathrm{~m}$ & $0.20 \mathrm{~m}$ & rect., pointed, $\triangle$-section & granite & no & ceremonial ctr. & L. Postclassic (95) \\
\hline & 6 & yes & $0.79 \mathrm{~m}$ & $0.23 \mathrm{~m}$ & $0.12 \mathrm{~m}$ & rect., pointed, $\triangle$-section & granite & no & ceremonial ctr. & L. Postclassic (95) \\
\hline & 7 & yes & $0.60 \mathrm{~m}$ & $0.17 \mathrm{~m}$ & $0.12 \mathrm{~m}$ & rect., pointed, $\nabla$-section & rhyolite & no & ceremonial ctr. & L. Postclassic (95) \\
\hline & 8 & yes & $0.62 \mathrm{~m}$ & $0.18 \mathrm{~m}$ & $0.13 \mathrm{~m}$ & rect., pointed, $\square$-section & granite & no & ceremonial ctr. & L. Postclassic (95) \\
\hline & 9 & yes & $0.65 \mathrm{~m}$ & $0.25 \mathrm{~m}$ & $0.16 \mathrm{~m}$ & oblong, pointed, $\triangle$-section & rhyolite & no & ceremonial ctr. & L. Postclassic (95) \\
\hline & 10 & no & $(0.43 \mathrm{~m})$ & $0.19 \mathrm{~m}$ & $0.14 \mathrm{~m}$ & rect., $\square$-section & granite & no & ceremonial ctr. & L. Postclassic (95) \\
\hline & 11 & yes & $0.74 \mathrm{~m}$ & $0.20 \mathrm{~m}$ & $0.15 \mathrm{~m}$ & rect., $\square$-section & rhyolite & no & ceremonial ctr. & L. Postclassic (95) \\
\hline & 12 & yes & $0.81 \mathrm{~m}$ & $0.37 \mathrm{~m}$ & $0.14 \mathrm{~m}$ & rect., pointed, $\square$-section & rhyolite & no & ceremonial ctr. & L. Postclassic (95) \\
\hline & 13 & no & $(0.85 \mathrm{~m})$ & $0.35 \mathrm{~m}$ & $0.12 \mathrm{~m}$ & rect., $\nabla$-section & rhyolite & no & ceremonial ctr. & L. Postclassic (95) \\
\hline & 14 & yes & $0.73 \mathrm{~m}$ & $0.16 \mathrm{~m}$ & $0.10 \mathrm{~m}$ & rect., pointed, $\triangle$-section & rhyolite & no & ceremonial ctr. & L. Postclassic (95) \\
\hline & 15 & no & $(0.76 \mathrm{~m})$ & $0.19 \mathrm{~m}$ & $0.17 \mathrm{~m}$ & rect., $\square$-section & rhyolite & no & ceremonial ctr. & L. Postclassic (95) \\
\hline & 16 & yes & $0.69 \mathrm{~m}$ & $0.27 \mathrm{~m}$ & $0.10 \mathrm{~m}$ & rect., $\square$-section & granite & no & ceremonial ctr. & L. Postclassic (95) \\
\hline & 17 & yes & $0.61 \mathrm{~m}$ & $0.23 \mathrm{~m}$ & $0.14 \mathrm{~m}$ & rect., $\square$-section & rhyolite & no & ceremonial ctr. & L. Postclassic (95) \\
\hline & 18 & no & $(0.64 \mathrm{~m})$ & $0.27 \mathrm{~m}$ & $0.14 \mathrm{~m}$ & rect., $\square$-section & rhyolite & no & ceremonial ctr. & L. Postclassic (95) \\
\hline & 19 & yes & $0.61 \mathrm{~m}$ & $0.23 \mathrm{~m}$ & $0.14 \mathrm{~m}$ & rect., pointed, $\square$-section & rhyolite & no & ceremonial ctr. & L. Postclassic (95) \\
\hline & 20 & yes & $0.78 \mathrm{~m}$ & $0.22 \mathrm{~m}$ & $0.12 \mathrm{~m}$ & rect., pointed, $\square$-section & granite & no & ceremonial ctr. & L. Postclassic (95) \\
\hline
\end{tabular}

